\title{
Article \\ Applicability of Calculation Formulae of Impact Force by Tsunami Driftage
}

\author{
Yoshimichi Yamamoto ${ }^{1, *}$, Yuji Kozono ${ }^{2}$, Erick Mas ${ }^{3}{ }^{\circ}$, Fumiya Murase ${ }^{4}$, Yoichi Nishioka ${ }^{5}$, Takako Okinaga ${ }^{6}$ \\ and Masahide Takeda ${ }^{7}$
}

check for updates

Citation: Yamamoto, Y.; Kozono, Y.; Mas, E.; Murase, F.; Nishioka, Y.; Okinaga, T.; Takeda, M. Applicability of Calculation Formulae of Impact Force by Tsunami Driftage. J. Mar. Sci. Eng. 2021, 9, 493. https://doi.org/ 10.3390/jmse9050493

Academic Editor: Eugen Rusu

Received: 31 December 2020

Accepted: 28 April 2021

Published: 1 May 2021

Publisher's Note: MDPI stays neutral with regard to jurisdictional claims in published maps and institutional affiliations.

Copyright: (c) 2021 by the authors. Licensee MDPI, Basel, Switzerland. This article is an open access article distributed under the terms and conditions of the Creative Commons Attribution (CC BY) license (https:/ / creativecommons.org/licenses/by/ $4.0 /)$.

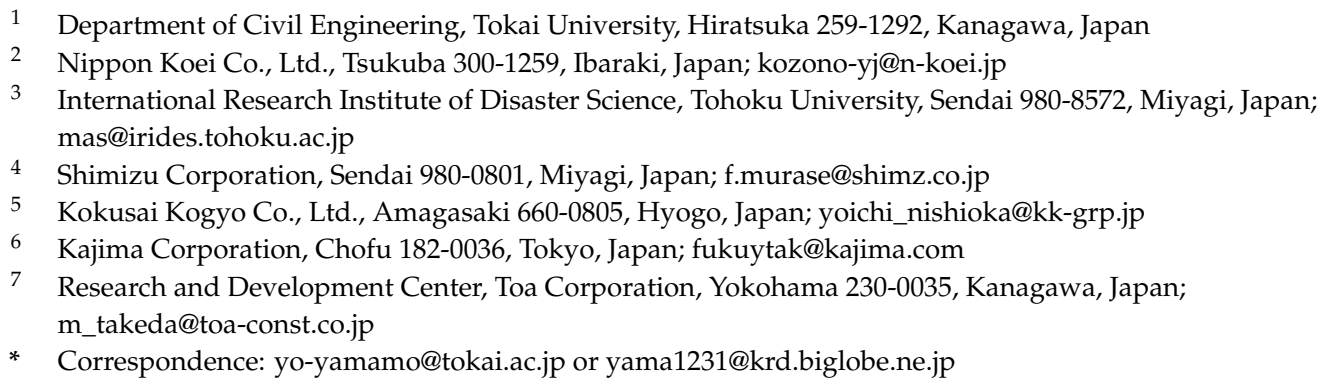

\begin{abstract}
The aftermath of the Indian Ocean tsunami on 26 December 2004 triggered by the off Sumatra earthquake (magnitude " $M$ " =9.1), and the Great East Japan earthquake of 11 March 2011 off the Pacific coast of Tohoku $(M=9.0)$, evidence the secondary damage from driftage collision due to large tsunami waves. To prevent this type of damage, the establishment of methods for predicting driftage movement and calculating the impact force by driftage is necessary. Several numerical models have been developed to predict the driftage movement of objects. Every year, these improve in accuracy and usability. In contrast, there are many calculation formulae for calculating the impact force. However, since there are considerable differences between values calculated using these formulae, the reliability of each formula is unknown. Therefore, in this research, one team of the committee on tsunami research of the Japan Society of Civil Engineers summarizes the main calculation formulae of impact forces that have been proposed until 2019. In addition, for each type of driftage (driftwood, containers, cars, ships), we compare calculation values of these formulae with measured data of large-scale experiments. Finally, we check the range of calculation values for each formula up to $15 \mathrm{~m} / \mathrm{s}$ in collision velocity and clarify then the following facts: (1) In the case of driftwood, the formulae of Matsutomi, Federal Emergency Management Agency (FEMA) and National Oceanic and Atmospheric Administration (NOAA), and American Society of Civil Engineers (ASCE) are most reliable; (2) In the case of containers, the formulae of Matsutomi, Arikawa et al., FEMA and NOAA, Ikeno et al., and ASCE are most reliable; (3) In the case of cars, the formulae of FEMA and NOAA, and ASCE are most reliable; (4) In the case of ships, the formulae of Mizutani, FEMA and NOAA, and ASCE are most reliable.
\end{abstract}

Keywords: car and ship; container; driftwood; impact force; large tsunami; tsunami driftage

\section{Introduction}

When a large tsunami caused by an earthquake reaches coastal communities, secondary damage by driftage and collision of objects is observed. For instance, when the damage surveys in Thailand (January 2005) and in Sri Lanka (May 2005) took place, following the off Sumatra earthquake (magnitude " $M^{\prime \prime}=9.1$ ) and the Indian Ocean tsunami, this type of damage was confirmed. Later, damage surveys conducted in Japan (March and April 2011) in the aftermath of the Great East Japan earthquake $(M=9.0)$ evidenced, once again, the significant damage caused by driftage and collision of objects. Some examples are shown in the following. 
(1) Driftwood

Figure 1a shows fallen trees that collided against a hotel at Khao Lak in Thailand, while Figure $1 \mathrm{~b}$ portraits some logs that pierced the windows of a building at Ofunato in Japan.
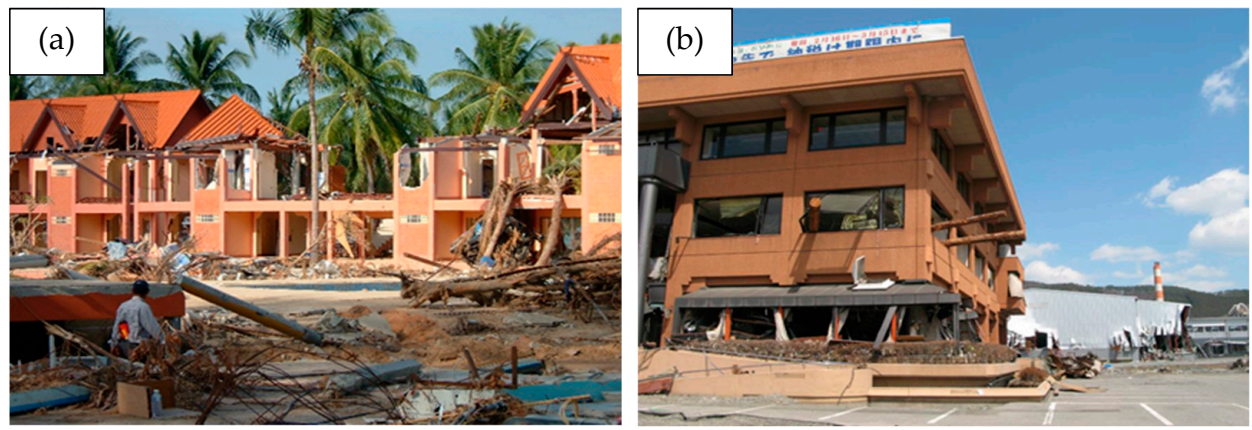

Figure 1. Damage from driftwood: (a) fallen trees collided against a hotel at Khao Lak in Thailand, and (b) some logs pierced the windows of a building at Ofunato in Japan.

(2) Containers

In Figure 2a, a container collided against a house near the coast at Hitachi in Japan. Similarly, in Figure 2b, a container broke the wall of a large warehouse at the Soma port in Japan.
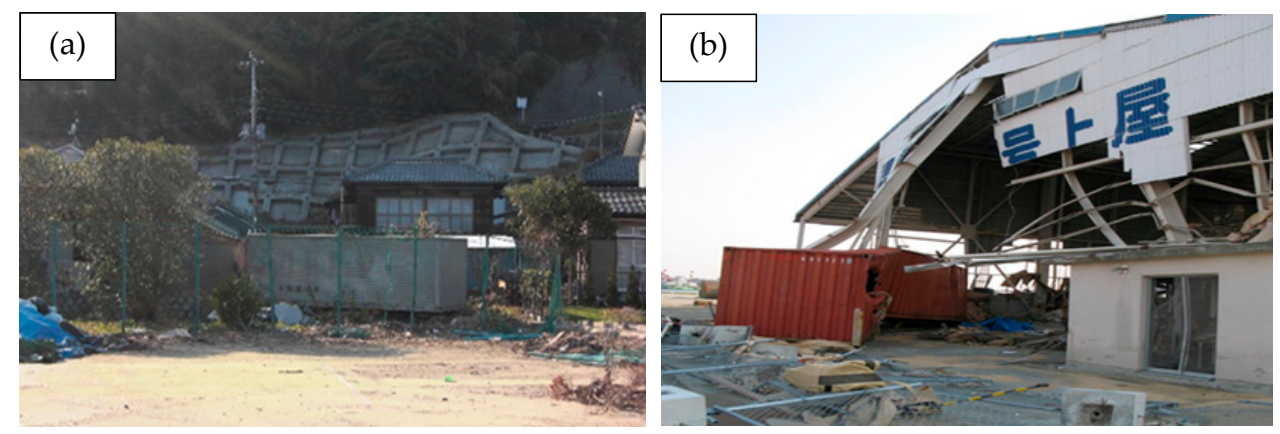

Figure 2. Damage from shipping containers: (a) a container collided against a house near the coast at Hitachi in Japan, and (b) a container broke the wall of a large warehouse at the Soma port in Japan.

\section{(3) Cars}

Figure 3a shows a dump truck that collided against a warehouse at the Kirinda fishing port in Sri Lanka. In Figure 3b, a passenger car collided against a shop at Miyako in Japan. Figure $3 c$ shows how cars were pushed against the corner of a school building at Sendai in Japan.
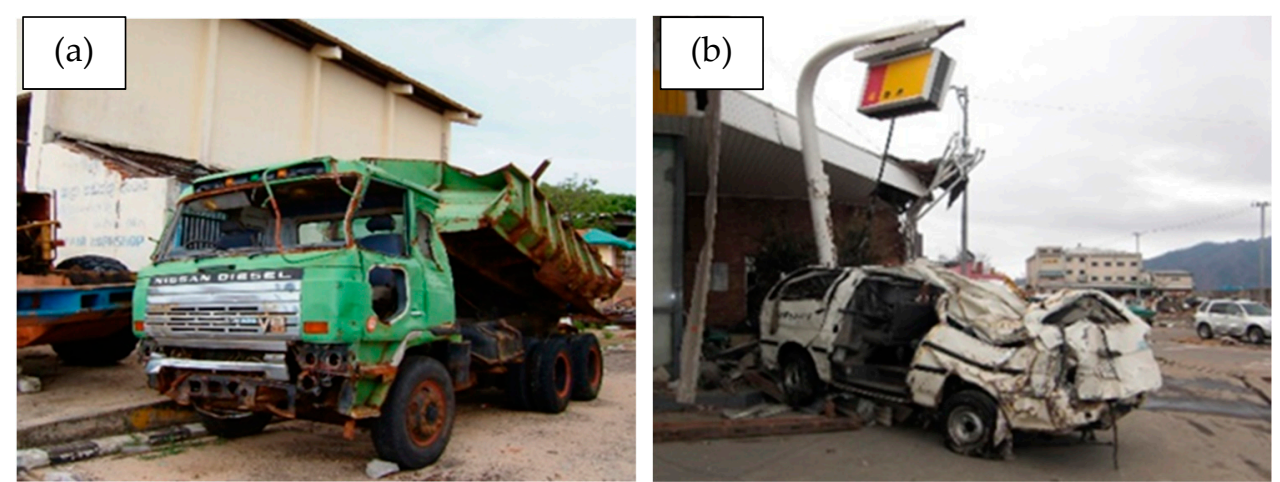

Figure 3. Cont. 


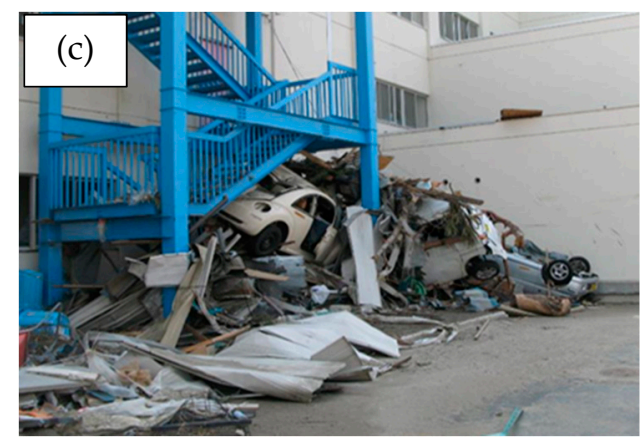

Figure 3. Damage from cars: (a) a dump truck collided against a warehouse at the Kirinda fishing port in Sri Lanka, (b) a passenger car collided against a shop at Miyako in Japan, and (c) many cars were pushed against the corner of a school building at Sendai in Japan.

\section{(4) Ships}

In Figure 4a, a patrol boat stopped at the foot of a mountain $1 \mathrm{~km}$ inland of Khao Lak in Thailand. In addition, Figure $4 \mathrm{~b}$ shows a building with a big hole made by the patrol boat in Khao Lak. On the other hand, Figure 4c shows a large fishing boat left behind in the ruins near a fishing port at Kesennuma in Japan. Figure 4d shows a broken steel frame building on the shortest line between the large fishing boat and the fishing port.
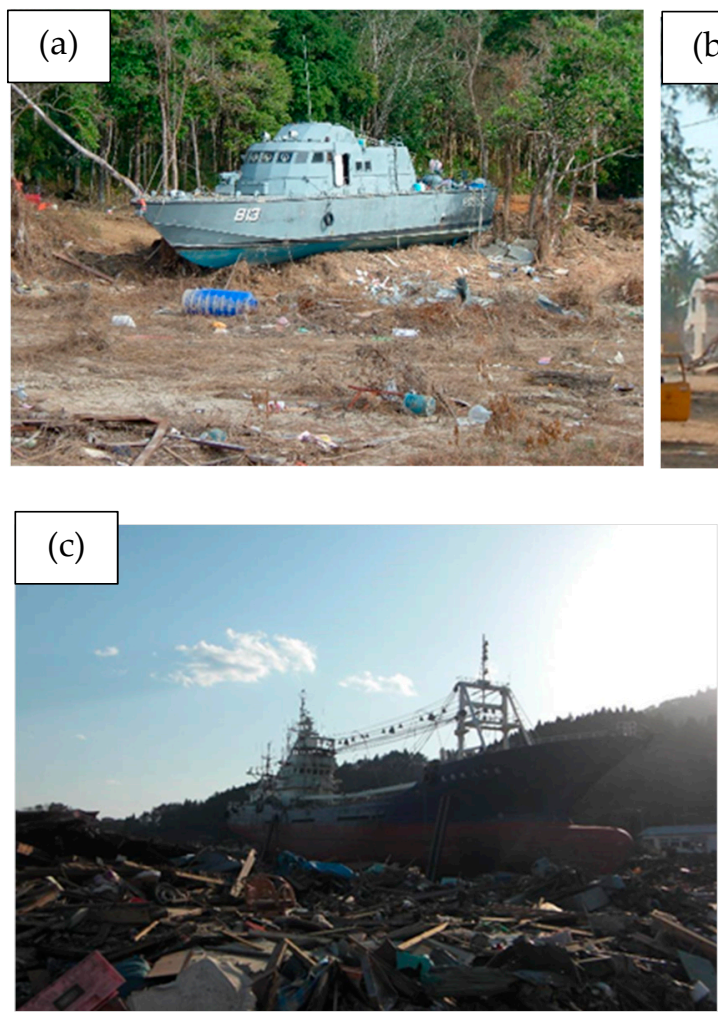

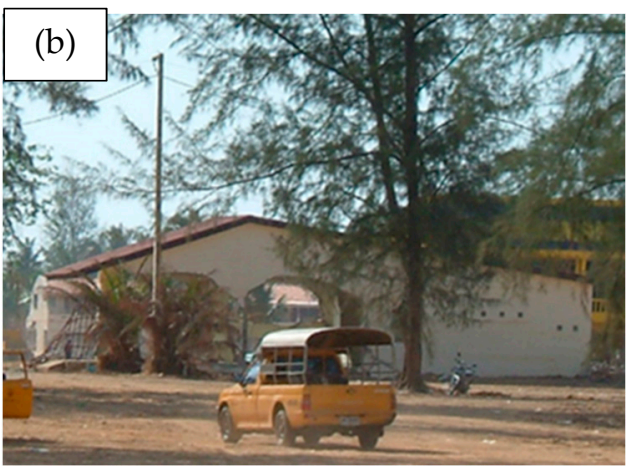

(d)

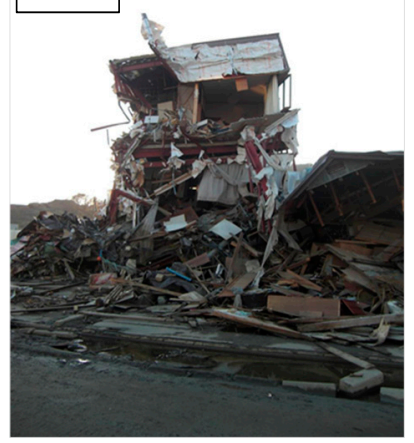

Figure 4. Damage due to ships: (a) a patrol boat stopped at the foot of a mountain located $1 \mathrm{~km}$ inland of Khao Lak in Thailand, (b) a building showing a big hole made by the patrol boat in Khao Lak in Thailand, (c) a large fishing boat left behind in the ruins near a fishing port at Kesennuma in Japan, and (d) a broken steel frame building that was located on the shortest line between the large fishing boat and the fishing port at Kesennuma in Japan.

To prevent damage by driftage, it is important to establish a method for predicting driftage movement and calculating the impact force by driftage. Nistor et al. [1] reviewed existing papers published until 2016 about the transportation and the impact force of debris caused by a tsunami. 
Experiential methods to predict driftage movement can be easily handled as the range at which driftage can reach is estimated based on simple assumptions, as demonstrated by Naito et al. [2]. In contrast, driftage movement can be evaluated through numerical simulations (Nistor et al. [1]), though the further improvement of the simulation accuracy and the convenience of the handling for engineers is desired. Regarding evaluation methods by numerical models, Yoneyama et al. [3] conducted a study by which the 3-dimensional VOF method was used for fluid motion calculation, and Murase et al. [4] used the storm surge and tsunami simulator in oceans and coastal areas (STOC) model.

For methods to calculate the impact force, although there are numerical models, such as the elastoplastic finite deformation analysis of Magoshi et al. [5], they have not reached the level at which they can be used simply and reliable for engineers. Thus, traditional methods generally used are semi-theoretical formulae and empirical formulae, as shown in Tables 1-3. However, since there are considerable differences between values calculated by these formulae, the reliability of each formula is unknown. In this regard, Kaida and Kihara [6] investigated calculation formulae of impact forces proposed until 2012, and they checked the performance range of calculated values by each formula up to a maximum value of collision velocity of $10 \mathrm{~m} / \mathrm{s}$. Finally, they summarized the calculation formulae that are effective for each type of driftage. Moreover, they compiled the appropriate values of shaft rigidity, which is an important parameter in some formulas presented in Tables 1-3. Furthermore, Stolle et al. $[7,8]$ indicated that the calculation accuracy of the impact force of low rigid debris (like driftwood, containers) could be improved by estimating the rigidity of the debris exactly.

Table 1. Impact force formula (no. 1).

\begin{tabular}{|c|c|c|}
\hline Driftage & Formula & Reference \\
\hline Driftwood & $\begin{array}{l}\qquad F_{i}=u_{\max } \sqrt{k\left(m_{d}+c_{M} m_{f}\right)} \times \beta e \\
\beta=\sin \varphi, e=\frac{1}{\sqrt{1+\left[\left(\frac{\varepsilon_{o}}{r_{i}}\right)\left(1+\mu \frac{r_{o}}{\varepsilon_{0}}\right)\right]}} \\
F_{i} \text { is the impact force }(\mathrm{N}) ; u_{\max } \text { is the maximum velocity of driftwood; } k \text { is } \\
\text { the effective contact stiffness; } m_{d} \text { is the mass of driftwood; } \\
c_{M} \text { is the added mass coefficient; } m_{f} \text { is the mass of displaced fluid; } \\
\beta \text { is the decreasing coefficient by the orientation angle } \varphi ; \\
e \text { is the decreasing coefficient by eccentricity; } \\
\varepsilon_{o} \text { is the length from the barycenter to the collided point; } \\
r_{i} \text { is the turning radius; } \mu \text { is the friction coefficient } \\
\text { between the driftwood and the collided body; } \\
r_{o} \text { is the radius of the sectional area of the driftwood. }\end{array}$ & Haehnel and Daly (2004) [9] \\
\hline Driftwood and Containers & $\begin{array}{c}F_{i}=\frac{\pi m u c_{I} c_{o} c_{D} c_{B} R_{\max }}{2 \Delta t}, \Delta t=\frac{\pi}{2} \sqrt{\frac{m}{k}} \\
F_{i} \text { is the impact force }(\mathrm{N}) ; m \text { is the mass of the driftage; } \\
u \text { is the collision velocity; } c_{I} \text { is the important factor; } \\
c_{o} \text { is the orientation coefficient; } c_{D} \text { is the coefficient of water depth; } \\
c_{B} \text { is the barrier coefficient; } R_{\max } \text { is the maximum response ratio to the } \\
\text { collision load; } \Delta t \text { is the continuing time of the collision; } \\
k \text { is the effective stiffness. }\end{array}$ & ASCE (2010) [10] \\
\hline $\begin{array}{l}\text { Driftwood (the Mass is about } \\
450 \mathrm{~kg} \text { ) and Containers (the } \\
\text { Empty Mass is } 2200-3800 \mathrm{~kg} \text { ) }\end{array}$ & $\begin{array}{c}F_{i}=1.3 u_{\max } \sqrt{m_{d} k(1+c)}, u_{\max }=\sqrt{2 g R\left(1-\frac{z}{R}\right)} \\
\qquad F_{i} \text { is the impact force }(\mathrm{N}) ; \\
1.3 \text { is the importance coefficient of risk category IV; } \\
u_{\max } \text { is the maximum fluid velocity; } m_{d} \text { is the mass of driftage; } \\
k \text { is the effective stiffness }\left(2.4 \times 10^{6} \mathrm{~N} / \mathrm{m} \text { to driftwood; }\right. \\
\quad 6.5 \times 10^{8} \mathrm{~N} / \mathrm{m} \text { to } 12.2 \mathrm{~m} \text { empty containers; } \\
1.5 \times 10^{9} \mathrm{~N} / \mathrm{m} \text { to } 6.1 \mathrm{~m} \text { empty containers); } \\
c \text { is the hydrodynamic mass coefficient } \\
(0.0 \text { to the long axis direction for the collision of driftwood; } \\
0.2 \text { to the long axis direction for the collision of } 12.2 \mathrm{~m} \text { containers; } \\
1.0 \text { to the transverse direction for the collision of } 12.2 \mathrm{~m} \text { containers; } \\
0.3 \text { to the long axis direction of } 6.1 \mathrm{~m} \text { containers; } \\
1.0 \text { to the transverse direction of } 6.1 \mathrm{~m} \text { containers); } \\
g \text { is the gravitational acceleration; } \\
R \text { is the maximum run-up height } \times 1.3 ; \\
z \text { is the ground height on the water surface. }\end{array}$ & FEMA \& NOAA (2012) [11] \\
\hline
\end{tabular}


Table 2. Impact force formula (no. 2).

\begin{tabular}{|c|c|c|}
\hline Driftage & Formula & Reference \\
\hline Driftwood, Containers, etc. & $\begin{array}{c}F_{i}=u \sqrt{k_{d} m_{d}}, k_{d}=\frac{E A_{d}}{L_{d}} \\
F_{i} \text { is the impact force }(\mathrm{N}), u \text { is the collision velocity; } \\
k_{d} \text { and } m_{d} \text { are the stiffness and the mass of driftage; } \\
E \text { is the elastic modulus of driftage; } \\
A_{d} \text { and } L_{d} \text { are the sectional area and the length of driftage. } \\
\text { The impulse duration of the steel tube can be obtained using } t_{d}=2 \sqrt{\frac{m_{d}}{k_{d}}}\end{array}$ & $\begin{array}{l}\text { Aghl, Naito, and } \\
\text { Riggs (2014) [12] }\end{array}$ \\
\hline $\begin{array}{c}\text { Driftwood, Containers } \\
\text { (6.1-12.2 m), Cars, Ships, etc. }\end{array}$ & $\begin{array}{l}\qquad F_{i}=R_{\max } I_{T S U} C_{o} u_{\max } \sqrt{k m_{d}} \\
\qquad F_{i} \text { is the impact force }(\mathrm{N}) ; \\
R_{\max } \text { is the dynamic response ratio to the collision load } \\
\text { (it is in the range of } 0.0-1.8 \text { according to the collision action time); } \\
I_{T S U} \text { is the importance factor (1.0-1.25); } \\
C_{o} \text { is the orientation coefficient }(=0.65) ; \\
u_{\max } \text { is the maximum fluid velocity; } \\
k \text { is the smaller one of (i) the stiffness of the driftage; } \\
\text { (ii) the transverse direction stiffness of the collided body; } \\
m_{d} \text { is the mass of the driftage. } \\
\text { The stiffness of the driftwood can be calculated by using } k=E A / L . \\
\text { sectional area and the length. } \\
\text { is the elasticity modulus of the long axis direction of driftage; } A \text { and } L \text { are the } \\
\text { The impulse duration for empty containers } t_{d} \text { can be calculated by using } t_{d}=2 \sqrt{\frac{m_{d}}{k}} \\
\text { The impulse duration for loaded containers } t_{d} \text { can be calculated by using } t_{d}=\frac{m_{d}+m_{\text {contents }}}{\sqrt{k m_{d}}}\end{array}$ & ASCE (2015) [13] \\
\hline
\end{tabular}

$$
F=\frac{W V^{2}}{4 g l_{d}}
$$

$F$ is the impact force $(\mathrm{kN}) ; W$ is the weight of the ship $(\mathrm{kN})$;

$V$ is the collision velocity; $l_{d}$ is the stopping distance.

Table of stopping distance of the ship

Ships

\begin{tabular}{|c|c|c|}
\hline Ship line & $\begin{array}{c}\text { Weight of the ship } \\
\text { (ton-force) }\end{array}$ & $\begin{array}{c}\text { Stopping distance } \\
\text { (m) }\end{array}$ \\
\hline Main line & 200,000 & 8 \\
\hline Side line & 5000 & 1 \\
\hline
\end{tabular}

$$
\frac{F}{\gamma D^{2} L}=1.6 C_{M A}\left\{\frac{V}{(g D)^{0.5}}\right\}^{1.2}\left(\frac{\sigma_{f}}{\gamma L}\right)^{0.4}
$$

$F$ is the impact force $(\mathrm{kN}) ; C_{M A}$ is the apparent mass coefficient (1.7 for a bore or a surge, 1.9 for a steady flow);

Driftwood (Long Axis Direction Collision)
$V$ is the collision velocity $(\mathrm{m} / \mathrm{s})$;

$D$ and $L$ are the diameter and the length of driftwood (m);

$\sigma_{f}$ is the yield stress of driftwood $\left(\mathrm{kN} / \mathrm{m}^{2}\right]$;

$\gamma$ is the unit weight of driftwood $\left(\mathrm{kN} / \mathrm{m}^{3}\right)$;

$g$ is the gravitational acceleration.

\begin{tabular}{|c|c|c|}
\hline Driftage & Formula & Reference \\
\hline Driftwood, Cars, Ships, etc. & $\begin{array}{c}F=0.1 \cdot W \cdot v \\
F \text { is the impact force }(\mathrm{kN}): W \text { is the weight of driftage }(\mathrm{kN}) \\
v \text { is the surface fluid velocity }(\mathrm{m} / \mathrm{s}) \text {. }\end{array}$ & $\begin{array}{l}\text { Japan Road Association } \\
\text { (2002) [16] }\end{array}$ \\
\hline Driftwood & 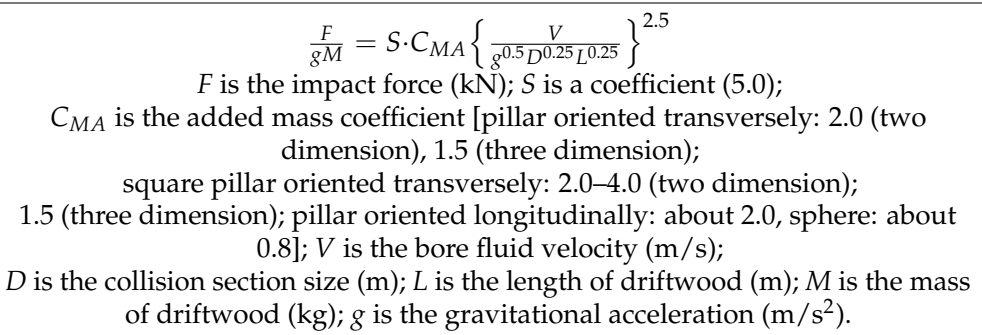 & Ikeno and Tanaka (2003) [17] \\
\hline
\end{tabular}

Table 3. Impact force formula (no. 3). 
Table 3. Cont.

\begin{tabular}{|c|c|c|}
\hline Driftage & Formula & Reference \\
\hline \multicolumn{3}{|c|}{$F=2 \rho_{w} \eta_{m} B_{c} V_{x}^{2}+\frac{W V_{x}}{g d t}$} \\
\hline Containers & $\begin{array}{l}F \text { is the impact force }(\mathrm{kN}) ; \rho_{w} \text { is the water density }\left(\mathrm{t} / \mathrm{m}^{3}\right) \\
\eta_{m} \text { is the maximum run-up height; } B_{c} \text { is the width of the container; } V_{X} \text { is the } \\
\text { drift velocity }(\mathrm{m} / \mathrm{s}) ; W \text { is the container weight; } g \text { is the gravitational acceleration; } \\
\qquad d t \text { is the collision time. }\end{array}$ & Mizutani et al. (2005) [18] \\
\hline Small Ships & $\begin{array}{l}\qquad F=2 \frac{W V_{x}}{g d t} \\
F \text { is the impact force }(\mathrm{kN}) ; W \text { is the weight of the small ship }(\mathrm{kN}) ; V_{X} \text { is the } \\
\text { drifting velocity of the small ship }(\mathrm{m} / \mathrm{s}) ; g \text { is the gravitational acceleration; } d t \text { is } \\
\text { the collision time. }\end{array}$ & Mizutaniet al. (2007) [19] \\
\hline Driftwood, Containers, etc. & $\begin{array}{l}\qquad F=\gamma_{p} \chi^{2 / 5}\left(\frac{5}{4} \widetilde{m}\right)^{3 / 5} V^{6 / 5} \\
\quad \chi=\frac{4 \sqrt{a}}{3 \pi} \frac{1}{k_{1}+k_{2}}, k_{i}=\frac{1-v_{i}^{2}}{\pi E_{i}} \\
\text { for the driftwood: } \widetilde{m}=C_{M A_{1} m_{1}} \\
\text { for the containers: } \widetilde{m}=\frac{m_{1} m_{2}}{m_{1}+m_{2}} \\
F \text { is the impact force }(\mathrm{kN}) ;\end{array}$ & $\begin{array}{c}\text { Arikawa et al. (2007) [20], } \\
\text { (2010) [21] }\end{array}$ \\
\hline Driftwood and Containers & $\begin{array}{l}\qquad F=k_{c}\left(C_{M A} M\right)^{0.6} V^{1.2} D^{0.2} E^{0.4} \\
F \text { is the impact force at the time of the elastic collision }(\mathrm{kN}) ; \\
k_{c} \text { is a constant } 0.243 ; C_{M A} \text { is the apparent mass coefficient }(2.0 \text { for wooden pillar } \\
\text { oriented longitudinally, } 1.0 \text { for containers); } M \text { is the mass of driftage }(\mathrm{kg}) ; V \text { is } \\
\text { the collision velocity }(\mathrm{m} / \mathrm{s}) ; D \text { is the collision sectional area size }(\mathrm{m}) ; E \text { is the } \\
\text { representative stiffness }=\frac{E_{1} \times E_{2}}{E_{1}\left(1-v_{2}^{2}\right)+E_{2}\left(1-v_{1}^{2}\right)}\end{array}$ & Ikeno et al. (2013) [22] \\
\hline
\end{tabular}

In this research, we summarize the main calculation formulae of impact forces proposed by 2019, and the calculation values by these formulae are compared with measured data of large-scale experiments for each type of driftage (driftwood, shipping containers, cars, ships). Moreover, the range of calculated values by each formula up to a collision velocity of $15 \mathrm{~m} / \mathrm{s}$ is investigated. Finally, the reliability of each formula is discussed and clarified.

\section{Accuracy of Formulae for Calculating the Impact Force}

\subsection{List of Main Calculation Formulae}

The main calculation formulae of impact forces by tsunami driftage proposed by 2019 are summarized in Tables 1-3. Although these calculation formulae were designed to reflect the proposer's experimental data, there are considerable differences among the proposed formulae. A possible reason for these differences might be that several formulae cannot make the difference in rigidity between the driftage and the collided body correctly into consideration. When the driftage collides with the collided body, the impact force is reduced by carrying out an elastic modification. Therefore, the impact force is different if the rigidity of the driftage or the collided body is not identical, even when the velocity at the time of collision is the same. In other words, if the differences of bodies with different rigidity from the experiment used to verify the proposed formula are not considered, the accuracy of the results is reduced.

In the case of the tsunami force in which seawater collides against a rigid body made of concrete or steel, the seawater deforms easily compared with the collided body. Moreover, the inverse of whole rigidity is proportional to the inverse of each rigidity of the collision body and the collided body. Therefore, we can say that the rigidity of the seawater is very low, and the decrease of the tsunami force is governed not by the collided body but by seawater. Therefore, we do not need to make the difference in rigidity of the collided body into consideration. 


\subsection{Correlation Examination of the Main Calculation Formulae}

We searched for large-scale experimental data with the size, weight, rigidity of the driftage and the collided body, the collision velocity, and the impact force for each driftage type (driftage, containers, cars, ships) in the published literature. We compare the calculated values of the impact force and measurements.

Here, as the improved formula of Haehnel and Daly [9] is the formula of FEMA and NOAA [11] and the improved formula of ASCE [10] and Aghl, Naito and Riggs [12] is the formula of ASCE [13], the formulae of Haehnel and Daly [9], ASCE [10], and Aghl, Naito and Riggs [12] are not examined.

Because we could not find materials, which can determine the stop distance of driftage except for ships, the formula of the Bridge and Engineering Association [14] was examined only for the case of ships. Moreover, since we could not find materials, which can determine the yield stress of ships, the formula of Matsutomi [15] was not examined for the case of ships. The formula of Mizutani et al. [18] was examined for containers and cars, which can estimate a maximum run-up height easily because they do not float and move immediately. In addition, the formula of [19] was examined in the case of ships. Moreover, for the formula of ASCE [13], the values for $R_{\max }, I_{T S U}, C_{o}$ were set as 1.8, 1.25, and 0.65 , respectively. Although ASCE [13] recommends some values for the effective stiffness $k$, when this was not available, the recommended values by FEMA and NOAA [11] were used.

\subsubsection{Driftwood}

Although there are many small-scale experiments, we selected the large-scale experiments of Matsutomi [15] and Ikeno et al. (Central Research Institute of Electric Power Industry) [23] because they specify necessary information, and we actually used the data for collision velocities larger than $2.0 \mathrm{~m} / \mathrm{s}$ in their experiments, which were measured in unsteady flow using a water flume.

The calculation conditions are as follows:

(1) Experiment 1 of Matsutomi [15]

(a) Parameters of the driftwood (larch)

$0.3 \mathrm{~m}$ in diameter, $2.1 \mathrm{~m}$ long, $78.67 \mathrm{~kg}, 25 \mathrm{MN} / \mathrm{m}^{2}$ yield stress, 0.4 Poisson's ratio, $8000 \mathrm{MN} / \mathrm{m}^{2}$ elasticity modulus.

(b) Parameters of the collided body (steel)

0.3 Poisson's ratio, 200,000 MN $/ \mathrm{m}^{2}$ elasticity modulus.

(c) Coefficients in the formula

Each apparent mass coefficient $C_{M A}$ was set up according to each proposer's recommended value (1.7 for Matsutomi [15], 2.0 for Ikeno and Tanaka [17], 1.7 for Arikawa et al. [20], 2.0 for Ikeno et al. [22]). The constant 0.0 was set up to the coefficient $C$ of FEMA and NOAA [11]. The axial stiffness $k_{1}$ of the driftwood was $269 \mathrm{MN} / \mathrm{m}$ (since the axial stiffness changes according to the dimensions of the object, the recommended value of FEMA and NOAA [11] is usable only to specified dimensions. Therefore, this value was calculated using the elasticity modulus of driftwood), and the bending stiffness $k_{2}$ of the steel was $5 \mathrm{MN} / \mathrm{m}$.

(d) Measured impact force and the collision velocity

The measured impact force and the collision velocity are $0.022 \mathrm{MN}$ and $2.0 \mathrm{~m} / \mathrm{s}$, respectively.

(2) Experiment 2 of Matsutomi [15]

(a) Parameters of the driftwood (larch)

$0.3 \mathrm{~m}$ in diameter, $2.7 \mathrm{~m}$ long, $101.15 \mathrm{~kg}, 25 \mathrm{MN} / \mathrm{m}^{2}$ yield stress, 0.4 Poisson's ratio, $8000 \mathrm{MN} / \mathrm{m}^{2}$ elasticity modulus.

(b) Parameters of the collided body (steel) and the apparent mass coefficients used the same values as (1) Matsutomi's experiment 1 [15].

(c) Coefficients in the formula; 
The coefficient $C$ of FEMA and NOAA [11] was chosen as 0.0 . The axial stiffness $k_{1}$ of the driftwood was $209 \mathrm{MN} / \mathrm{m}$, and the bending stiffness $k_{2}$ of the steel was $5 \mathrm{MN} / \mathrm{m}$.

(d) Measured impact force and the collision velocity

The measured impact force and the collision velocity are $0.026 \mathrm{MN}$ and $2.0 \mathrm{~m} / \mathrm{s}$, respectively.

(3) Matsutomi's experiment 3 [15]

(a) Parameters of the driftwood (larch)

$0.3 \mathrm{~m}$ in diameter, $4.0 \mathrm{~m}$ long, $149.85 \mathrm{~kg}, 25 \mathrm{MN} / \mathrm{m}^{2}$ yield stress, 0.4 Poisson's ratio, $8000 \mathrm{MN} / \mathrm{m}^{2}$ elasticity modulus

(b) Parameters of the collided body (steel) and the apparent mass coefficients used the same values as (1) Matsutomi's experiment 1 [15].

(c) Coefficients in the formula;

The coefficient $C$ of FEMA and NOAA [11] was 0.0 . The axial stiffness $k_{1}$ of the driftwood was $141 \mathrm{MN} / \mathrm{m}$, and the bending stiffness $k_{2}$ of the steel was $5 \mathrm{MN} / \mathrm{m}$.

(d) Measured impact force and the collision velocity

The measured impact force and the collision velocity are $0.036 \mathrm{MN}$ and $2.0 \mathrm{~m} / \mathrm{s}$, respectively.

(4) Experiment 1 of Ikeno et al. [23];

(a) Parameters of the driftwood (pine);

$0.42 \mathrm{~m}$ in diameter, $2.0 \mathrm{~m}$ long, $177.0 \mathrm{~kg}, 25 \mathrm{MN} / \mathrm{m}^{2}$ yield stress, 0.4 Poisson's ratio, $11,200 \mathrm{MN} / \mathrm{m}^{2}$ elasticity modulus.

(b) Parameters of the collided body (steel) and the apparent mass coefficients used the same values as (1) Matsutomi's experiment 1 [15].

(c) Coefficients in the formula;

The coefficient $C$ of FEMA and NOAA [11] was 0.0 . The axial stiffness $k_{1}$ of the driftwood was $776 \mathrm{MN} / \mathrm{m}$, and the bending stiffness $k_{2}$ of the steel was $12.8 \mathrm{MN} / \mathrm{m}$.

(d) Measured impact force and the collision velocity;

The measured impact force and the collision velocities are $0.080 \mathrm{MN}$ and $2.0 \mathrm{~m} / \mathrm{s}$, $0.082 \mathrm{MN}$ and $4.0 \mathrm{~m} / \mathrm{s}$, respectively.

(5) Experiment 2 of Ikeno et al. [23]

(a) Parameters of the driftwood (cedar)

$0.382 \mathrm{~m}$ in diameter, $1.0 \mathrm{~m}$ long, $73.0 \mathrm{~kg}, 23 \mathrm{MN} / \mathrm{m}^{2}$ yield stress, 0.4 Poisson's ratio, $9100 \mathrm{MN} / \mathrm{m}^{2}$ elasticity modulus.

(b) Parameters of the collided body (steel) and the apparent mass coefficients used the same values as (1) Matsutomi's experiment 1 [15].

(c) Coefficients in the formula;

The coefficient $C$ of FEMA and NOAA [11] was 0.0 . The axial stiffness $k_{1}$ of the driftwood was $1040 \mathrm{MN} / \mathrm{m}$, and the bending stiffness $k_{2}$ of the steel was $12.8 \mathrm{MN} / \mathrm{m}$.

(d) Measured impact force and the collision velocity

The measured impact force and the collision velocity are $0.054 \mathrm{MN}$ and $4.1 \mathrm{~m} / \mathrm{s}$, respectively.

(6) Experiment 3 of Ikeno et al. [23];

(a) Parameters of the driftwood (cedar)

$0.382 \mathrm{~m}$ in diameter, $2.0 \mathrm{~m}$ long, $156.0 \mathrm{~kg}, 23 \mathrm{MN} / \mathrm{m}^{2}$ yield stress, 0.4 Poisson's ratio, $9100 \mathrm{MN} / \mathrm{m}^{2}$ elasticity modulus.

(b) Parameters of the collided body (steel) and the apparent mass coefficients used the same values as (1) Matsutomi's experiment 1 [15].

(c) Coefficients in the formula

The coefficient $C$ of FEMA and NOAA [11] was 0.0 . The axial stiffness $k_{1}$ of the driftwood was $521 \mathrm{MN} / \mathrm{m}$, and the bending stiffness $k_{2}$ of the steel was $12.8 \mathrm{MN} / \mathrm{m}$. 
(d) Measured impact force and the collision velocity

The measured impact force and the collision velocity are $0.077 \mathrm{MN}$ and $4.1 \mathrm{~m} / \mathrm{s}$, respectively. The verification results are shown in Figure 5.

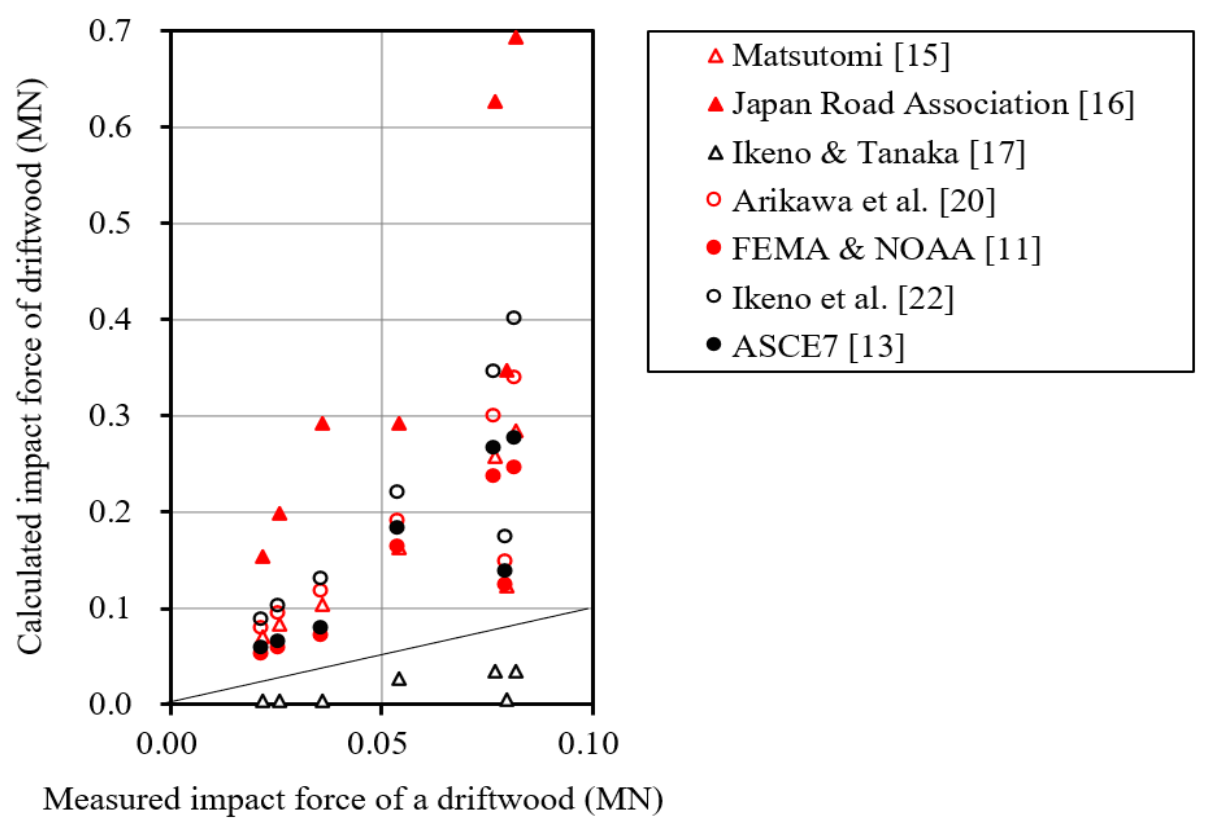

Figure 5. Comparison of impact forces for driftwood.

The Japan Road Association's formula [16] overestimates, and Ikeno and Tanaka's formula [17] underestimates the measured data. The formulae of FEMA and NOAA [11], ASCE [13], and Matsutomi [15] result in values reasonably close to the measured values. Since the formulae of Arikawa et al. [20] and Ikeno et al. [22] correlate well with measured values, provided the formulae are improved so that parameters concerning the rigidity of the driftage and the collided body can be decided adequately, the calculation accuracy of the improved formulae will improve.

\subsubsection{Containers}

Large-scale experiments with the necessary information were conducted by Aghl et al. [12] and Arikawa et al. [20] (Port and Airport Research Institute). Only data with collision velocities larger than $1.4 \mathrm{~m} / \mathrm{s}$ were used. The experiment of Aghl et al. [12] was implemented in the air by using a full-scale container, and the experiment of Arikawa et al. [20] was conducted in unsteady flow using a water flume and a container model of 1:5 in scale. Moreover, when using the formula of Mizutani et al. [18], $1000 \mathrm{~kg} / \mathrm{m}^{3}$ was used for $\rho_{\mathrm{w}}$ since freshwater was used in their experiment, and half of the height of their containers was used for $\eta_{m}$ so that $2 \times \eta_{m} \times B_{c}$ becomes a collision sectional area. Furthermore, the impulse duration of ASCE [13] was used for $d t$.

The calculation conditions are as follows:

(1) Experiment of Arikawa et al. [20]

(a) Parameters of the small container (steel)

$0.5 \mathrm{~m}$ high, $1.21 \mathrm{~m}$ long, $62.00 \mathrm{~kg}, 250 \mathrm{MN} / \mathrm{m}^{2}$ yield stress, 0.3 Poisson's ratio, 200,000 MN/ $\mathrm{m}^{2}$ elasticity modulus.

(b) Parameters of the collided body (concrete)

0.2 Poisson's ratio, 25,000 MN/ $\mathrm{m}^{2}$ elasticity modulus.

(c) Coefficients in the formula 
Each apparent mass coefficient $C_{M A}$ was set up according to each proposer's recommendation value (1.7 for Matsutomi [15], 4.0 for Ikeno and Tanaka [17], 1.0 for Ikeno et al. [22]). The coefficient $C$ of FEMA and NOAA [11] was 0.2. The axial stiffness $k_{1}$ of the small container was $1080 \mathrm{MN} / \mathrm{m}$ (since the axial stiffness changes according to the dimensions of the object, the recommended value of FEMA and NOAA [11] cannot be used. Therefore, this value was calculated using the elasticity modulus of the small container), and the bending stiffness $k_{2}$ of the concrete was $2220 \mathrm{MN} / \mathrm{m}$.

(d) Measured impact force and the collision velocity

The measured impact force and the collision velocities are $0.033 \mathrm{MN}$ and $1.70 \mathrm{~m} / \mathrm{s}$, $0.049 \mathrm{MN}$ and $2.15 \mathrm{~m} / \mathrm{s}, 0.057 \mathrm{MN}$ and $2.40 \mathrm{~m} / \mathrm{s}$, respectively.

(2) Experiment of Aghl et al. [12]

(a) Parameters of the $6.1 \mathrm{~m}$ container (steel)

$2.5 \mathrm{~m}$ high, $6.1 \mathrm{~m}$ long, $2300 \mathrm{~kg}, 250 \mathrm{MN} / \mathrm{m}^{2}$ yield stress, 0.3 Poisson's ratio, $200,000 \mathrm{MN} / \mathrm{m}^{2}$ elasticity modulus.

(b) Parameters of the collided body (steel)

0.3 Poisson's ratio, 200,000 MN $/ \mathrm{m}^{2}$ elasticity modulus.

(c) Coefficients in the formula

Each apparent mass coefficient $C_{M A}$ was set up as the ones in the air (1.0 for Matsutomi [15], 2.0 for Ikeno and Tanaka [17], 1.0 for Ikeno et al. [22]). The constant 0.0 and $85 \mathrm{MN} / \mathrm{m}$, which FEMA and NOAA [11] recommends, were set up for the coefficient $C$ and the effective stiffness $k$ of FEMA and NOAA [11], respectively. Moreover, $42.9 \mathrm{MN} / \mathrm{m}$ recommended by ASCE [13] was set up for the effective stiffness $k$ of ASCE [13].

(d) Measured impact force and the collision velocity

The measured impact force and the collision velocities are $0.795 \mathrm{MN}$ and $1.43 \mathrm{~m} / \mathrm{s}$, $0.995 \mathrm{MN}$ and $1.80 \mathrm{~m} / \mathrm{s}, 1.195 \mathrm{MN}$ and $2.13 \mathrm{~m} / \mathrm{s}, 1.315 \mathrm{MN}$ and $2.42 \mathrm{~m} / \mathrm{s}$, respectively.

The verification results are shown in Figure 6.
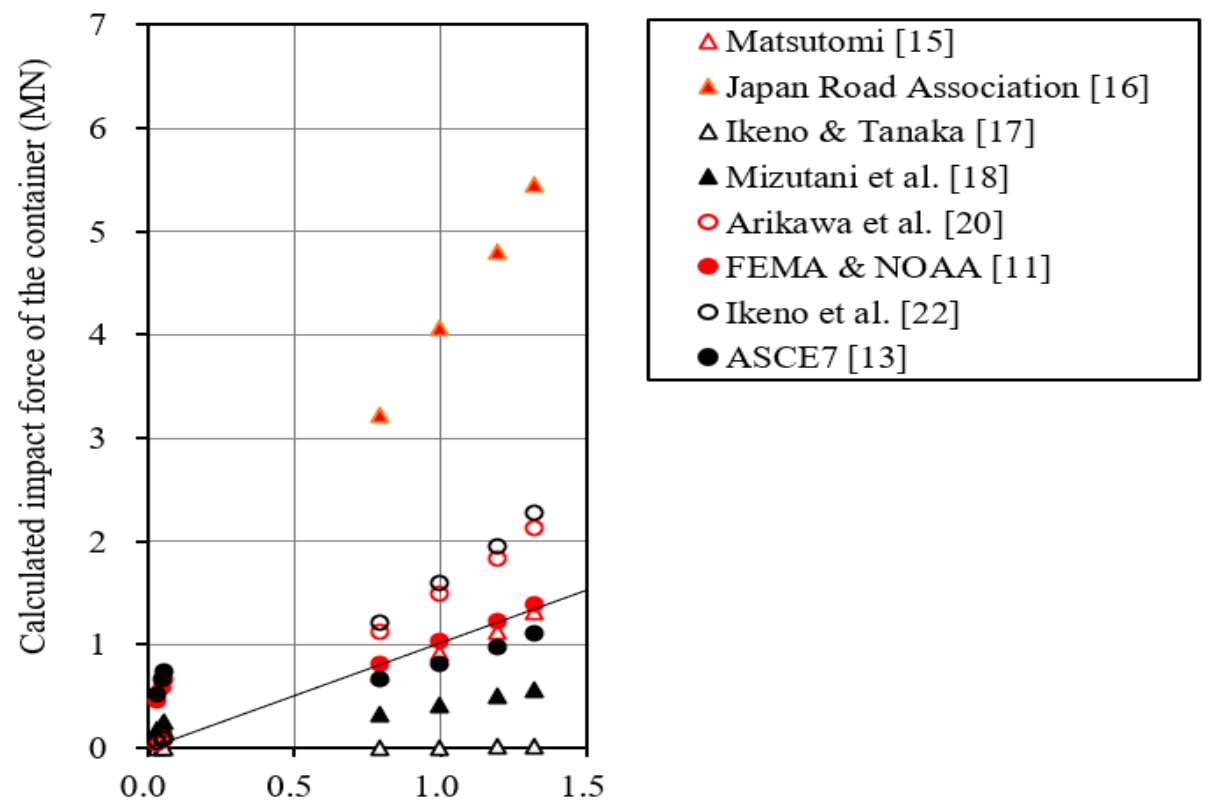

Measured impact force of the container (MN)

Figure 6. Comparison of impact forces for the containers.

The formula of the Japan Road Association [16] overestimates, and the formula of Ikeno and Tanaka [17] underestimates the measured data. The formulae of FEMA and 
NOAA [11], ASCE [13], and Matsutomi [15] provide values near the measured values. Since the formulae of Mizutani et al. [18], Arikawa et al. [20], and Ikeno et al. [22] show good correlations with the measured values, provided the formulae are improved so that parameters concerning rigidity of the driftage and the collided body can be decided adequately, the calculation accuracy of the improved formulae will improve.

\subsubsection{Car}

Unique large-scale experiments with all necessary information were conducted by Takabatake et al. [24] (Central Research Institute of Electric Power Industry). On the other hand, when using the formula of Mizutani et al. [18], $1000 \mathrm{~kg} / \mathrm{m}^{3}$ was used for $\rho_{\mathrm{W}}$, and half of the height of their car was used for $\eta_{\mathrm{m}}$. Furthermore, the impulse duration of ASCE [13] was used for $\mathrm{dt}$.

The calculation conditions are as follows:

\section{(a) Parameters of the actual car}

$1.48 \mathrm{~m}$ high, $1.40 \mathrm{~m}$ wide, $3.30 \mathrm{~m}$ long, $316.0 \mathrm{~kg}, 83,700 \mathrm{~N} / \mathrm{m}^{2}$ yield stress (from data when the buckling occurred in Takabatake et al. [24]), 0.3 Poisson's ratio. The elasticity modulus was calculated by using the empirical equation of the axial stiffness $(\mathrm{kN} / \mathrm{m})$ $(=457.41 \times$ collision velocity-170.79 $)$ obtained from measured data of Takabatake et al. [24].

(b) Parameters of the collided body (steel)

0.3 Poisson's ratio, 200,000 MN/ $\mathrm{m}^{2}$ elasticity modulus.

(c) Coefficients in the formula

Each apparent mass coefficient $C_{M A}$ was set up according to each proposer's recommended value (1.7 for Matsutomi [15], 2.0 for Ikeno and Tanaka [17], 2.0 for Ikeno et al. [22]). The coefficient $C$ of FEMA and NOAA [11] was 0.4. The effective stiffness $k$ was set up using the empirical equation obtained from measured data of Takabatake et al. [24].

(d) Measured impact force and the collision velocity

The measured impact force and the collision velocities are $0.003 \mathrm{MN}$ and $0.39 \mathrm{~m} / \mathrm{s}$, $0.024 \mathrm{MN}$ and $0.98 \mathrm{~m} / \mathrm{s}, 0.040 \mathrm{MN}$ and $1.78 \mathrm{~m} / \mathrm{s}, 0.042 \mathrm{MN}$ and $1.86 \mathrm{~m} / \mathrm{s}, 0.053 \mathrm{MN}$ and $2.07 \mathrm{~m} / \mathrm{s}, 0.039 \mathrm{MN}$ and $2.12 \mathrm{~m} / \mathrm{s}, 0.087 \mathrm{MN}$ and $3.90 \mathrm{~m} / \mathrm{s}$, respectively.

The verification results are shown in Figure 7.

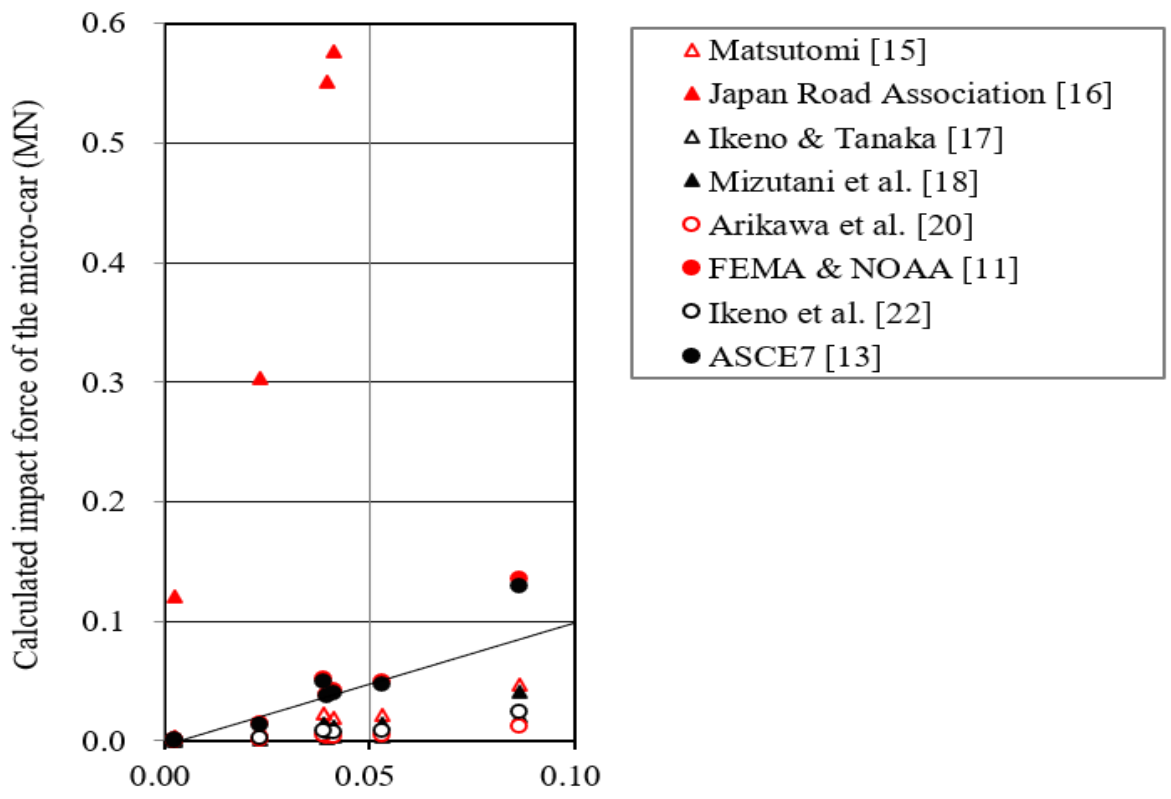

Measured impact force of the micro-car (MN)

Figure 7. Comparison of impact forces for the microcar. 
The formula of the Japan Road Association [16] overestimates the experimental values. The formulae of FEMA and NOAA [11] and ASCE [13] result in values near the measurements. Although the formulae of Matsutomi [15], Ikeno and Tanaka [17], Mizutani et al. [18], Arikawa et al. [20], and Ikeno et al. [22] underestimate the measurements, their predictions show a good correlation with measured values. Therefore, provided their formulae are improved so that parameters concerning the rigidity of the driftage and the collided body can be decided adequately, the calculation accuracy of the improved formulae will improve.

\subsubsection{Ship}

The large-scale experiments of Arita [25] (National Maritime Research Institute) were the only ones with all the necessary information. Even though in his experiment, a full-scale steel bow model collides against a steel pier model, it was also implemented in air, and the information, which we can use, is only a semi-theoretical formula based on data of this experiment. Moreover, since this formula consists only of the gross tonnage and the collision speed, this formula can only be applied when the conditions of the driftage and the collided body are in agreement with those of the experiment (other similar formulae cannot be used as general-purpose formulae owing to the same reason). When using the formula of Mizutani et al. [19], the impulse duration of ASCE [13] was used for $d t$.

The calculation conditions are as follows:

(a) Parameters of the ship (500 GTs)

$9.6 \mathrm{~m}$ wide, $50.0 \mathrm{~m}$ long, 1,500,000 kg, $0.51 \mathrm{~m}$ in stop distance (from the recommended values of the Bridge and Engineering Association [14]), 0.3 Poisson's ratio, 5,308,660 N/m in axial stiffness (from the data table for the axial stiffness of Takabatake et al. [24]), $5,760,000 \mathrm{~N} / \mathrm{m}^{2}$ elasticity modulus calculated from the axial stiffness by inverse analysis.

(b) Parameters of the collided body (steel)

0.3 Poisson's ratio, 200,000 MN/m² elasticity modulus.

(c) Coefficients in the formula

Each apparent mass coefficient $C_{M A}$ was set up according to each proposer's recommended value (1.5 for Ikeno and Tanaka [17], 1.0 for Ikeno et al. [22]). The coefficient $C$ of FEMA and NOAA [11] was 0.4. The effective stiffness $k$ was set up using the data table for the axial stiffness of Takabatake et al. [24].

(d) Measured impact force and the collision velocity

The measured impact force and the collision velocities are $1.96 \mathrm{MN}$ and $0.8 \mathrm{~m} / \mathrm{s}$, 2.94 $\mathrm{MN}$ and $1.2 \mathrm{~m} / \mathrm{s}, 3.92 \mathrm{MN}$ and $1.6 \mathrm{~m} / \mathrm{s}, 4.90 \mathrm{MN}$ and $2.0 \mathrm{~m} / \mathrm{s}, 5.88 \mathrm{MN}$ and $2.4 \mathrm{~m} / \mathrm{s}$, respectively.

The formula of Ikeno and Tanaka [17] underestimates the experimental values.!The formula of Mizutani et al. [19] results in values very close to the experimental ones.

Although the formulae of FEMA and NOAA [11] and ASCE [13] overestimate the experimental values, their formulae have given values close to the experimental ones.

Although the formulae of the Bridge and Engineering Association [14], Japan Road Association [16], Arikawa et al. [20], and Ikeno et al. [22] underestimate the measured values, their formulae show good correlations with the experimental values. Therefore, provided their formulae are improved so that parameters concerning the rigidity of the driftage and the collided body can be decided adequately, the calculation accuracy of the improved formulae will improve.

The reason why the calculated values of each formula in Figure 5 are not aligned along the straight line as in Figures 6-8 is because the accuracies of the measured values are low since wood is a natural material and the collision angle of wood relative to the collided body is a sensitive parameter for the result. Moreover, the elasticity modulus and the stiffness of wood also vary significantly. In other cases, the materials of the driftage were fixed, and especially in the case of the full-scale air experiments, since collision angles 
were right-angled relatively to the collided body, there is no difference due to the collision angles in the measured impact forces.

The verification results are shown in Figure 8.

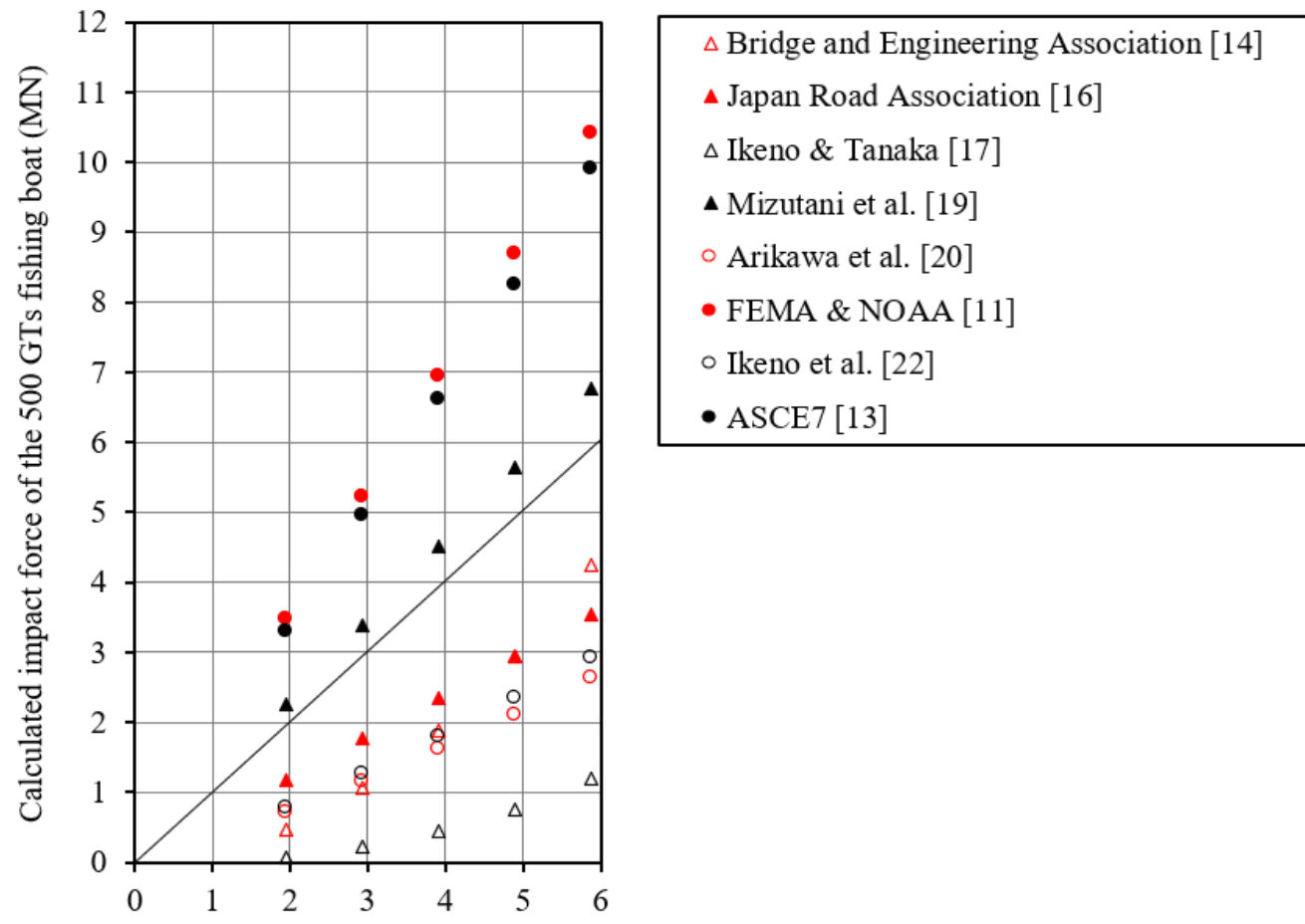

Measured impact force of the 500 GTs shipping boat (MN)

Figure 8. Comparison of impact forces for the ship.

\subsection{Range of Impact Force of Each Formula}

The collision velocity of the experimental data used for comparison with the previous section was not fast $(0.39 \mathrm{~m} / \mathrm{s}-4.1 \mathrm{~m} / \mathrm{s})$, and the range was small. Therefore, to check the validity of the calculation range of each formula, in the collision velocity range of $1 \mathrm{~m} / \mathrm{s}-15$ $\mathrm{m} / \mathrm{s}$, a general size was set up for each driftage type, and the impact force was calculated.

In addition, when the specific gravity of the driftage is larger than 1, the collision velocity must be lower than the tsunami velocity. Moreover, when a tsunami flow collides with a body with a large vertical plane, a backward flow occurs near the body. Therefore, as the driftage approaches the body, the collision velocity must become small by the backward flow. However, these influences are not considered.

\subsubsection{Driftwood}

(a) Parameters of a slender wood (pine and cedar);

$0.12 \mathrm{~m}$ in diameter, $1.6 \mathrm{~m}$ long, $11.56 \mathrm{~kg}, 34.3 \mathrm{MN} / \mathrm{m}^{2}$ yield stress, 0.4 Poisson's ratio, $10,000 \mathrm{MN} / \mathrm{m}^{2}$ elasticity modulus.

(b) Parameters of a thick wood (pine and cedar);

$0.51 \mathrm{~m}$ in diameter, $1.33 \mathrm{~m}$ long, $173.6 \mathrm{~kg}, 34.3 \mathrm{MN} / \mathrm{m}^{2}$ yield stress, 0.4 Poisson's ratio, $10,000 \mathrm{MN} / \mathrm{m}^{2}$ elasticity modulus.

(c) Parameters of the collided body (concrete);

0.167 Poisson's ratio, $25,000 \mathrm{MN} / \mathrm{m}^{2}$ elasticity modulus.

(d) Coefficients in the formula;

Each apparent mass coefficient $C_{M A}$ was set up according to each proposer's recommended value. (1.7 for Matsutomi [15], 2.0 for Ikeno and Tanaka [17], 1.7 for Arikawa et al. [20], 
2.0 for Ikeno et al. [22]). The coefficient $C$ of FEMA and NOAA [11] was 0.0. The effective stiffness $k$ of the slender wood was $20.1 \mathrm{MN} / \mathrm{m}$ (this value was calculated using the elasticity modulus of the slender wood), and the effective stiffness $k$ of the thick wood was $27.5 \mathrm{MN} / \mathrm{m}$.

The results are shown in Figure 9. The formula of Ikeno and Tanaka [17] gives too small values compared with the mean values of all formulae.

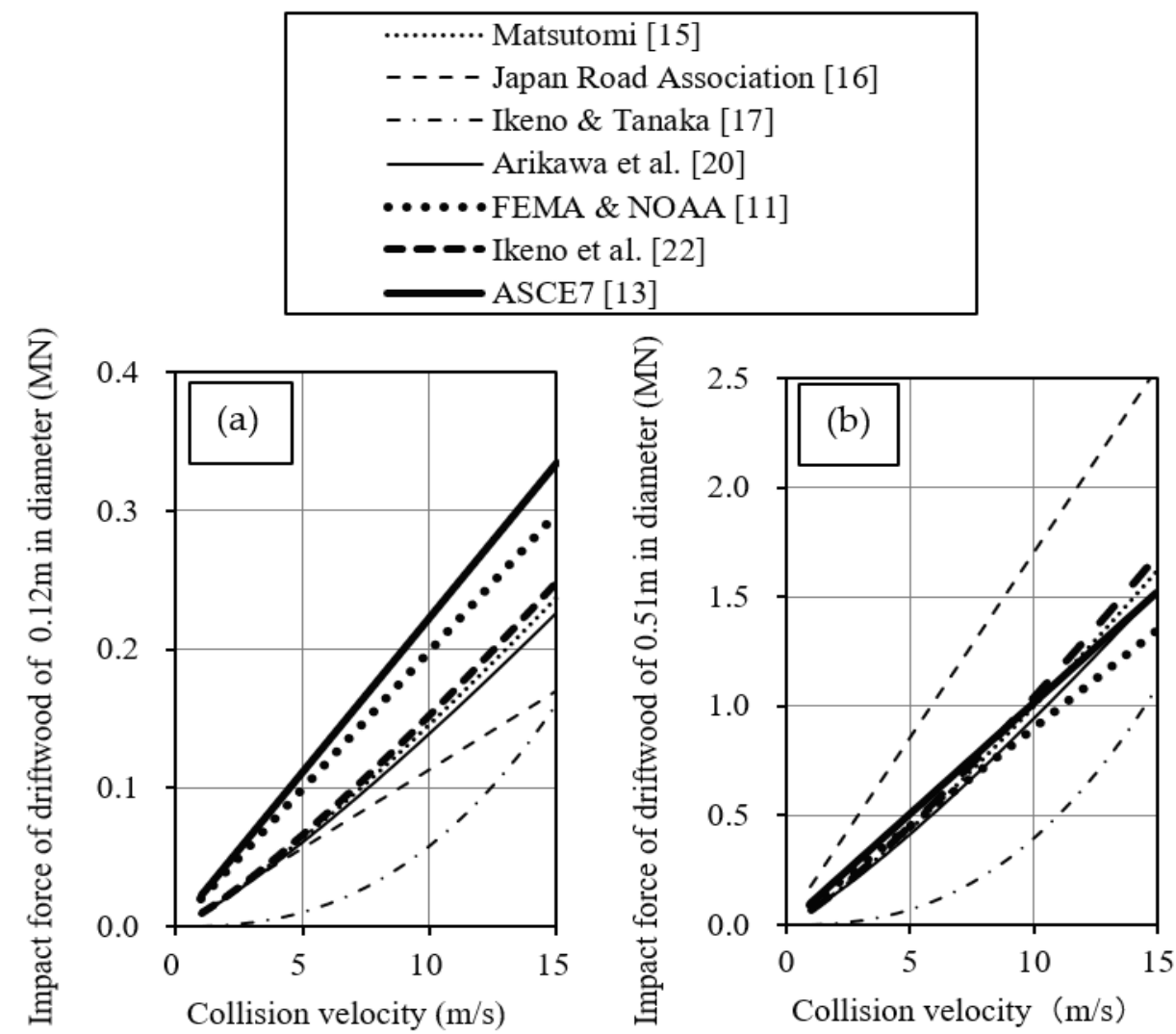

Figure 9. Impact force of driftwood: (a) the case of the slender wood, and (b) the case of the thick wood.

\subsubsection{Containers}

(a) Parameters of an empty $12.2 \mathrm{~m}$ container;

$2.45 \mathrm{~m}$ high, $12.1 \mathrm{~m}$ long, $3800 \mathrm{~kg}, 250 \mathrm{MN} / \mathrm{m}^{2}$ yield stress, 0.3 Poisson's ratio, 200,000 MN/m² elasticity modulus.

(b) Parameters of a fully-loaded $12.2 \mathrm{~m}$ container;

$2.45 \mathrm{~m}$ high, $12.1 \mathrm{~m}$ long, $72,600 \mathrm{~kg}, 250 \mathrm{MN} / \mathrm{m}^{2}$ yield stress, 0.3 Poisson's ratio, 200,000 MN/ $\mathrm{m}^{2}$ elasticity modulus.

(c) Parameters of the collided body (concrete);

0.167 Poisson's ratio, $25,000 \mathrm{MN} / \mathrm{m}^{2}$ elasticity modulus.

(d) Coefficients in the formula;

Each apparent mass coefficient $C_{M A}$ was set up according to each proposer's recommended value (1.7 for Matsutomi [15], 4.0 for Ikeno and Tanaka [17], 1.0 for Ikeno et al. [22]). The constant 0.2 and $60 \mathrm{MN} / \mathrm{m}$ recommended by FEMA and NOAA [11] were set up for the coefficient $C$ and the effective stiffness $k$ of FEMA and NOAA [11], respectively. Moreover, $29.8 \mathrm{MN} / \mathrm{m}$ recommended by ASCE [13] was set up for the effective stiffness $k$ of ASCE [13]. 
When using the formula of Mizutani et al. [18], the density $\rho_{\mathrm{w}}$ was $1000 \mathrm{~kg} / \mathrm{m}^{3}$ and half of the height of their containers was used for $\eta_{m}$. Furthermore, the impulse duration of ASCE [13] was used for $d t$.

The results are shown in Figure 10. The formula of the Japan Road Association [16] gives too big values as compared with the mean values of all formulae.

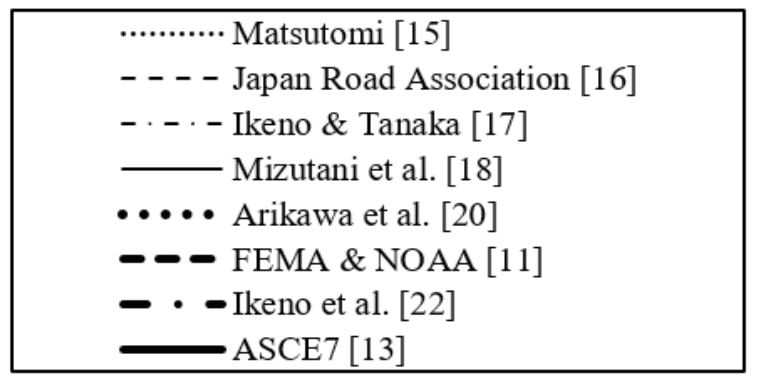

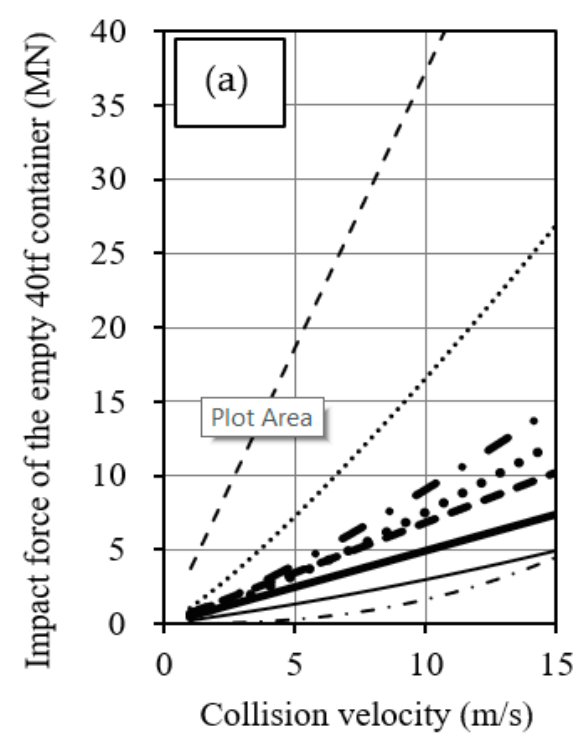

Figure 10. Impact force of the $12.2 \mathrm{~m}$ container: loaded container.

\subsubsection{Car}

(a) Parameters of an actual car

$1.80 \mathrm{~m}$ high, $2.00 \mathrm{~m}$ wide, $5.00 \mathrm{~m}$ long, $2500 \mathrm{~kg}, 47,800 \mathrm{~N} / \mathrm{m}^{2}$ yield stress (from data when the buckling occurred in Takabatake et al. [24]), 0.3 Poisson's ratio. The elastic modulus was calculated by using the empirical equation of the axial stiffness $(\mathrm{kN} / \mathrm{m})$ (=457.41 $\times$ collision velocity-170.79) obtained from measured data of Takabatake et al. [24].

(b) Parameters of the collided body (concrete)

0.2 Poisson's ratio, $25,000 \mathrm{MN} / \mathrm{m}^{2}$ elasticity modulus.

(c) Coefficients of the formula

Each apparent mass coefficient $C_{M A}$ was set up according to each proposer's recommendation value (1.7 for Matsutomi [15], 2.0 for Ikeno and Tanaka [17], 2.0 for Ikeno et al. [22]). The coefficient $C$ of FEMA and NOAA [11] was 0.4 . The effective stiffness $k$ was set up using the empirical equation obtained from measured data of Takabatake et al. [24].

Moreover, when using the formula of Mizutani et al. [18], the density $\rho_{\mathrm{W}}$ was 1000 $\mathrm{kg} / \mathrm{m}^{3}$, and half of the height of the car was used for $\eta_{m}$. Furthermore, the impulse duration of ASCE [13] was used for $d t$. 
The calculation results are shown in Figure 11. The formula of the Japan Road Association [16] gives too big values as compared with the mean values of all formulae.
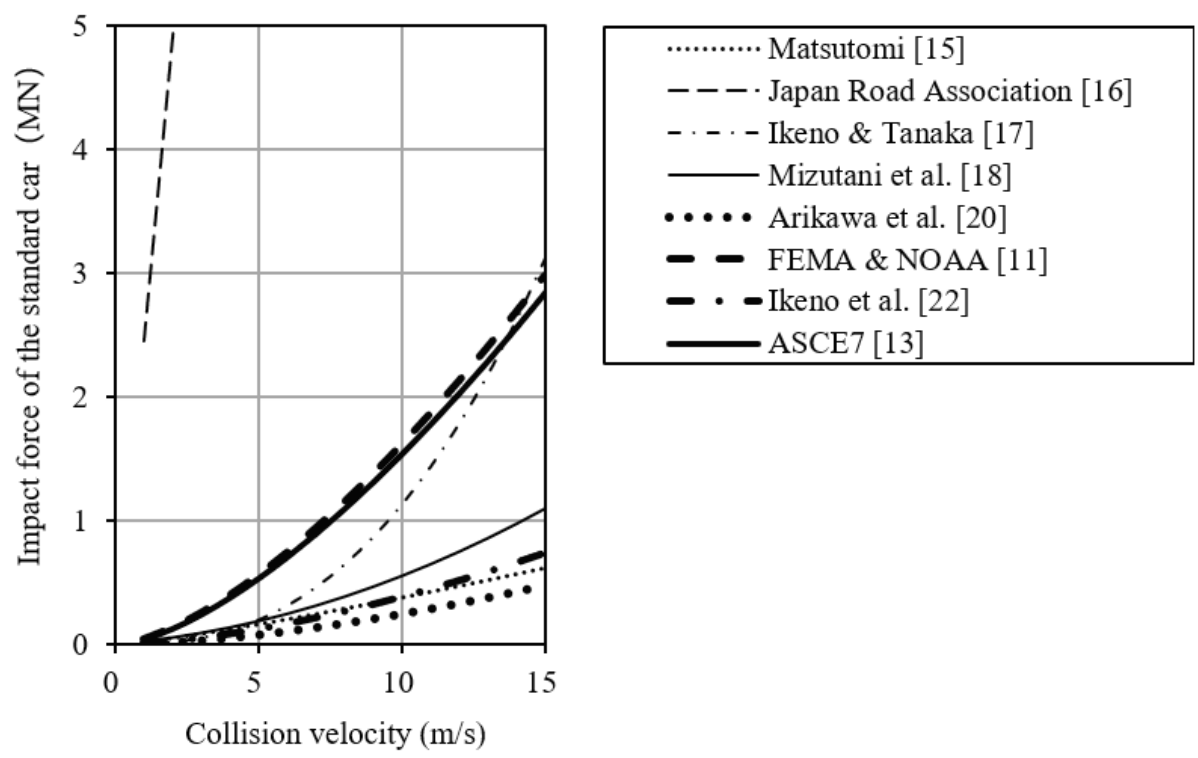

Figure 11. Impact force of the standard car.

\subsubsection{Ships}
(a) Parameters of a 5 GT ship

$2.8 \mathrm{~m}$ wide, $11.0 \mathrm{~m}$ long, 15,000 kg, $0.04 \mathrm{~m}$ in stop distance (from recommended values of the Bridge and Engineering Association [14]), 0.3 Poisson's ratio, 1144,950 N/m in axial stiffness (from the data table for the axial stiffness of Takabatake et al. [24]), 3,210,000 N/m² elasticity modulus calculated from the axial stiffness by inverse analysis.

(b) Parameters of a 500 GT ship

$9.4 \mathrm{~m}$ wide, $55.0 \mathrm{~m}$ long, 1,500,000 kg, $0.51 \mathrm{~m}$ in stop distance (from recommended values of the Bridge and Engineering Association [14]), 0.3 Poisson's ratio, 5,308,660 N/m in axial stiffness (from the data table for the axial stiffness of Takabatake et al. [24]), $6,610,000 \mathrm{~N} / \mathrm{m}^{2}$ elasticity modulus calculated from the axial stiffness by inverse analysis.

(c) Parameters of the collided body (concrete)

0.2 Poisson's ratio, 25,000 MN/m² elasticity modulus.

(d) Coefficients in the formula

Each apparent mass coefficient $C_{M A}$ was set up according to each proposer's recommended value (1.5 for Ikeno and Tanaka [17], 1.0 for Ikeno et al. [22]). The coefficient $C$ of FEMA and NOAA [11] was 0.4. The effective stiffness $k$ was set up using the data table for the axial stiffness of Takabatake et al. [24].

When using the formula of Mizutani et al. [19], the impulse duration of ASCE [13] was used for $d t$.

The calculation results are shown in Figure 12. The formula of the Bridge and Engineering Association [14] gives too big values as compared with the mean values. The formula of the Japan Road Association [16] gives small values as compared with the mean values of all formulae. 

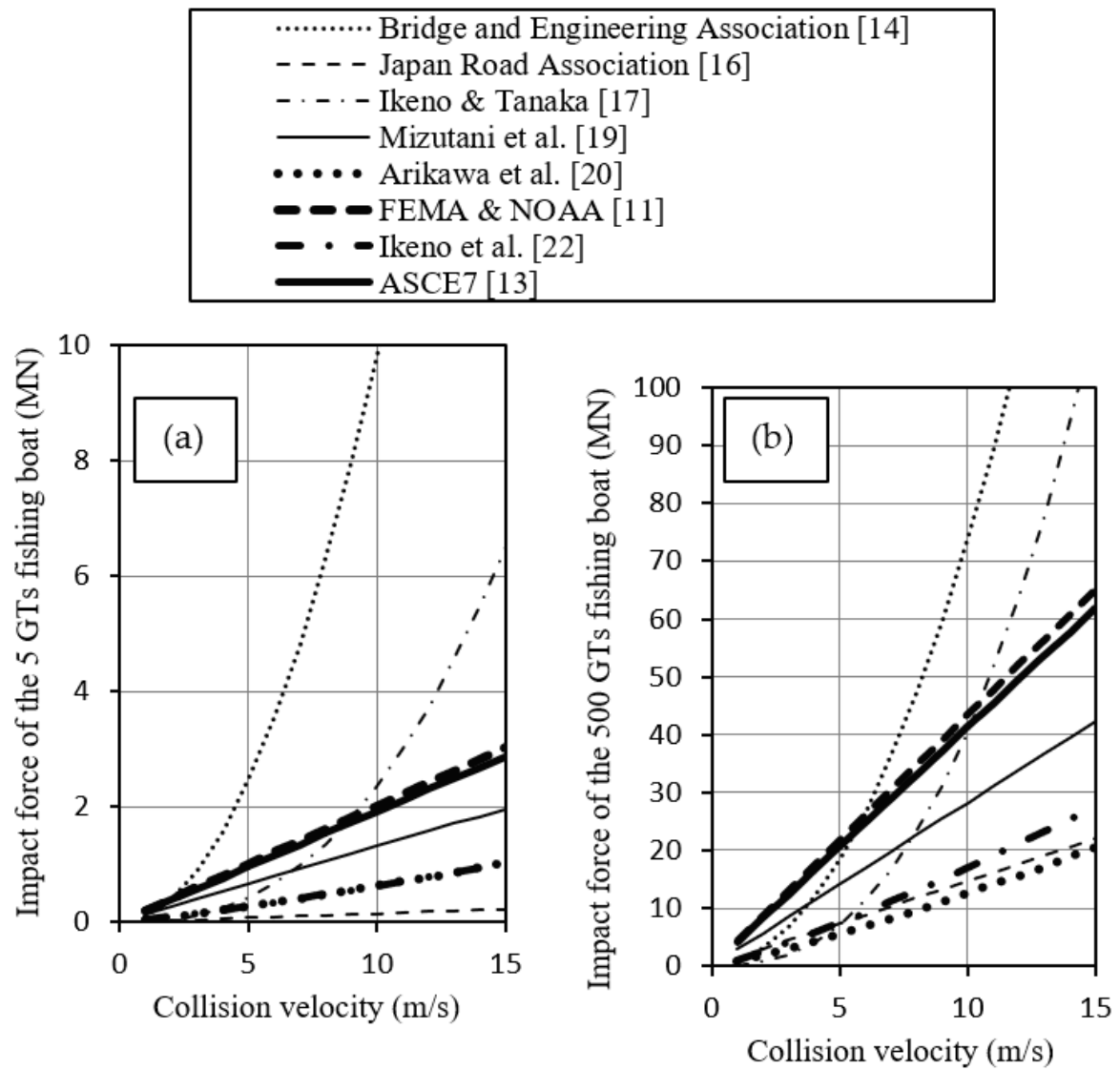

Figure 12. Impact force of the fishing boat: (a) the case of the 5 GTs boat, and (b) the case of the 500 GTs boat.

\section{Reliability Examination of Main Formulae}

Concerning the calculated and measured values of the impact force in Section 2.2, we classified formulae, which considerably overestimate or underestimate as " $\times$ ", formulae, which overestimate moderately or give values near the measured values as " $\bigcirc$ " and formulae, which give intermediate values of these formulae as " $\triangle$ ". Moreover, in examining the range of the calculated values in Section 2.3, since true values are not known, we classified formulae, which give too large or too small values compared with the mean values of all formulae as " $x$ ". Then, we judged that only formulae classified as " $\bigcirc$ " in Section 2.2 and were not classified as " $x$ " in Section 2.3 should be used because their reliability is high, and formulae, which were classified as " $x$ " in both sections should not be used. These results are shown in Table 4.

Table 4. Results of the reliability examination of impact force formulae.

\begin{tabular}{|c|c|c|c|c|c|c|c|c|c|c|}
\hline Driftage & Examination Type & $\begin{array}{l}\text { Bridge and Eng. } \\
\text { Assoc. [14] }\end{array}$ & Matsutomi [15] & $\begin{array}{l}\text { Japan Road } \\
\text { Assoc. [16] }\end{array}$ & $\begin{array}{l}\text { Ikeno and } \\
\text { Tanaka [17] }\end{array}$ & $\begin{array}{l}\text { Mizutani } \\
\text { et al. }[18,19]\end{array}$ & $\begin{array}{l}\text { Arikawa } \\
\text { et al. [20] }\end{array}$ & $\begin{array}{l}\text { FEMA and } \\
\text { NOAA [11] }\end{array}$ & $\begin{array}{c}\text { Ikeno } \\
\text { et al. [22] }\end{array}$ & ASCE [13] \\
\hline \multirow{3}{*}{ Driftwood } & Correlation & & 0 & $x$ & $x$ & & $\triangle$ & 0 & $\triangle$ & 0 \\
\hline & Existence range & & & & $x$ & & & & & \\
\hline & Reliability & & 0 & & $\times$ & & & 0 & & 0 \\
\hline \multirow{3}{*}{ Container } & Correlation & & 0 & $x$ & $x$ & $\triangle$ & O & $\mathrm{O}$ & $\mathrm{O}$ & $\mathrm{O}$ \\
\hline & Existence range & & & $x$ & & & & & & \\
\hline & Reliability & & 0 & $\times$ & & & 0 & 0 & 0 & 0 \\
\hline \multirow{3}{*}{ Car } & Correlation & & $\triangle$ & $x$ & $x$ & $\triangle$ & $x$ & 0 & $x$ & 0 \\
\hline & Existence range & & & $x$ & & & & & & \\
\hline & Reliability & & & $\times$ & & & & 0 & & 0 \\
\hline \multirow{3}{*}{$\begin{array}{c}\text { Fishing } \\
\text { Boat }\end{array}$} & Correlation & $\triangle$ & & $\triangle$ & $x$ & 0 & $\triangle$ & 0 & $\triangle$ & 0 \\
\hline & Existence range & $x$ & & $\times$ & & & & & & \\
\hline & Reliability & & & & & 0 & & 0 & & 0 \\
\hline
\end{tabular}


The following can be concluded based on Table 4:

(1) In the case of driftwood, the calculation formulae of Matsutomi [15], FEMA and NOAA [11] and ASCE [13] are most reliable.

(2) In the case of containers, the calculation formulae of Matsutomi [15], Arikawa et al. [20], FEMA and NOAA [11], Ikeno et al. [22], and ASCE [13] are most reliable.

(3) In the case of cars, the calculation formulae of FEMA and NOAA [11] and ASCE [13] are the most reliable.

(4) In the case of ships, the calculation formulae of Mizutani [19], FEMA and NOAA [11], and ASCE [13] are the most reliable.

However, when FEMA and NOAA [11] and ASCE [13] are used, although the appropriate stiffness is very important, it is very difficult to estimate the appropriate stiffness of complicated structures. Moreover, the stiffness changes according to the change of collision velocity. Therefore, we used the stiffness recommended by FEMA and NOAA [11] and ASCE [13] in the case of a $6.1 \mathrm{~m}$ container and a $12.2 \mathrm{~m}$ container, and the recommended stiffness of Takabatake et al. [24] or Kaida and Kihara [6] for cars and ships.

Moreover, since the formulae of the Bridge and Engineering Association [14], Matsutomi [15], Mizutani et al. [18,19], Arikawa et al. [20], and Ikeno et al. [22] show good correlations with the measured values, if the formulae were improved so that parameters concerning the rigidity of the driftage and the collided body could be considered, the reliability of the formulae becomes better, and the applicability range also increases.

On the other hand, since the formula of the Japan Road Association [16] cannot make the difference in rigidity of the driftage and the collided body into consideration and tends to give an excessive impact force, it is better to avoid its use. In addition, since the formula of Ikeno and Tanaka [17] can also not make the difference in rigidity of the driftage and the collided body into consideration and tends to give a too small impact force, it is better to avoid its use.

\section{Conclusions}

There are many formulae for calculating the impact forces from driftage. Since there are considerable differences between the calculated values of these formulae, the reliability of each formula was assessed here. We summarized the main calculation formulae of the impact force proposed by 2019 and compared the calculation values of these formulae with the measured data from large-scale experiments. Furthermore, we checked the range of the calculation values of each formula up to $15 \mathrm{~m} / \mathrm{s}$ in collision velocity and then clarified the following points:

(1) In the case of driftwood, the formulae of Matsutomi [15], FEMA and NOAA [11], and ASCE [13] are the most reliable;

(2) In the case of containers, the formulae of Matsutomi [15], Arikawa et al. [20], FEMA and NOAA [11], Ikeno et al. [22], and ASCE [13] are most reliable;

(3) In the case of cars, the formulae of FEMA and NOAA [11] and ASCE [13] are the most reliable;

(4) In the case of ships, the formulae of Mizutani [19], FEMA and NOAA [11], and ASCE [13] are the most reliable.

Here, except for the formulae of the Japan Road Association [16] and Ikeno and Tanaka [17], the stiffness or parameters governed by rigidity (stop distance of ships, yield stress, collision time, elasticity modulus) must be set appropriately:

(a) When FEMA and NOAA [11] and ASCE [13] are used, the stiffness recommended by FEMA and NOAA [11] and ASCE [13] can be used for the $6.1 \mathrm{~m}$ container and the $12.2 \mathrm{~m}$ container, and the stiffness recommended by Takabatake et al. [24] or Kaida and Kihara [6] can be used for cars and ships;

(b) Since the formulae of the Bridge and Engineering Association [14], Matsutomi [15], Mizutani et al. [18,19], Arikawa et al. [20], and Ikeno et al. [22] show good correlations with the measured values, provided the formulae are improved so that parameters 
concerning the rigidity of the driftage and the collided body can be considered, the reliability of the formulae is expected to increase, and the applicable scope to become larger;

(c) Since the formulae of the Japan Road Association [16] and Ikeno and Tanaka [17] cannot make the difference in rigidity of the driftage and the collided body into consideration, the applicable range of their formulae is limited. Moreover, the former tends to give an excessive impact force, and the latter tends to give a too small impact force. Therefore, it is desirable to avoid using their equations.

Author Contributions: Conceptualization, Y.Y. and M.T.; methodology, Y.Y. and M.T.; software (Excel sheets for calculating the impact forces), Y.Y., Y.K., Y.N. and M.T.; validation, Y.Y. and M.T.; formal analysis, all members; investigation, all members; resources, all members; data curation, Y.Y.; writing—original draft preparation, Y.Y.; writing—review and editing, Y.Y, E.M.; visualization, supervision, Y.Y.; project administration, M.T. All authors have read and agreed to the published version of the manuscript.

Funding: This research was partly funded by the grant-in-aid for scientific research (c; 18k04667) of JSPS and the Core Research Cluster of Disaster Science at Tohoku University. We express our deepest gratitude.

Institutional Review Board Statement: This research dose not involve humans or animals.

Informed Consent Statement: This research dose not involve humans.

Data Availability Statement: In this research, all photos were taken by authors and all data used for calculations are open data from the references.

Conflicts of Interest: The authors declare no conflict of interest.

\section{References}

1. Nistor, I.; Goseberg, N.; Stolle, J. Tsunami-Driven Debris Motion and Loads: A Critical Review. Front. Built Environ. 2017, 3. [CrossRef]

2. Naito, C.; Cercone, C.; Riggs, H.R.; Cox, D. Procedure for Site Assessment of the Potential for Tsunami Debris Impact. J. Waterw. Port Coastal Ocean Eng. 2014, 140, 223-232. [CrossRef]

3. Yoneyama, N.; Tanaka, Y.; Pringle, J.W.; Nagashima, H. The development of three dimensional numerical analysis for tsu-nami driven debris in real scale senarios and its basic verification. J. JSCE B2 (Coast. Eng.) 2015, 71, 1027-1032. (In Japanese)

4. Murase, F.; Teramoto, N.; Toyoda, A.; Tanaka, Y.; Arikawa, T. Examination for Evaluation Method of Collision Probability of Tsunami Debris Using Numerical Calculation. J. Jpn. Soc. Civ. Eng. Ser. B2 (Coast. Eng.) 2019, 75, I_439-I_444. [CrossRef]

5. Magoshi, K.; Ge, H.; Nonaka, T.; Harada, T.; Murakami, K. Collision Simulation of A Large Flotsam and A Long-Span Bridge in A Tsunami. J. Jpn. Soc. Civ. Eng. Ser. B3 (Ocean Eng.) 2012, 68, 222-227. [CrossRef]

6. Kaida, H.; Kihara, N. Evaluation Technologies for the Impact Assessment of Tsunami Debris on Nuclear Power Plants-Review of Current Status and Discussion on the Application; Central Research Institute of Electric Power Industry: Tokyo, Japan, 2017; Volume o16010, 45p. (In Japanese)

7. Stolle, J.; Derschum, C.; Goseberg, N.; Nistor, I.; Petriu, E. Debris impact under extreme hydrodynamic conditions part 2: Impact force responses for non-rigid debris collisions. Coast. Eng. 2018, 141, 107-118. [CrossRef]

8. Stolle, J.; Nistor, I.; Goseberg, N.; Petriu, E. Multiple Debris Impact Loads in Extreme Hydrodynamic Conditions. J. Waterw. Port Coast. Ocean Eng. 2020, 146, 04019038. [CrossRef]

9. Haehnel, R.; Daly, S.F. Maximum impact force of woody debris on floodplain structures. J. Hydraul. Eng. 2004, 130, 112-120. [CrossRef]

10. ASCE. ASCE/SEI, Standard 7-10, Minimum Design Loads for Buildings and Other Structures; ASCE: Virginia, WA, USA, 2010.

11. FEMA. Guidelines for Design of Structures for Vertical Evacuation from Tsunamis, 2nd ed.; FEMA: Washington, DC, USA, 2012.

12. Aghl, P.P.; Naito, C.J.; Riggs, H.R. Full-Scale Experimental Study of Impact Demands Resulting from High Mass, Low Velocity Debris. J. Struct. Eng. 2014, 140, 04014006. [CrossRef]

13. ASCE. Standard 7, Chapter 6, Tsunami Loads and Effects; ASCE: Virginia, WA, USA, 2015.

14. Marine Bridge Research Committee. Honshu Shikoku Bridge Technical Standards, Lower Volume, Sub-Structure Design Standards and Explanations; Bridge and Engineering Association: Tokyo, Japan, 1978. (In Japanese)

15. Matsutomi, H. A practical formula for estimating impulsive force due to driftwoods and variation features of the impulsive force. Doboku Gakkai Ronbunshu 1999, 621, 111-127. (In Japanese) [CrossRef]

16. Japan Road Association. Specifications for a Highway Bridge and Explanations, Part I Common; Japan Road Association: Tokyo, Japan, 2002; pp. 65-67. (In Japanese) 
17. Ikeno, M.; Tanaka, H. Experimental study on impulse force of drift body and tsunami running up to land. JSCE. Coast. Eng. 2003, 50, 721-725. (In Japanese)

18. Mizutani, N.; Takagi, Y.; Shiraishi, K.; Miyajima, S.; Tomita, T. Study on wave force on a container on apron due to tsunamis and collision force of drifted container. Annu. J. Coast. Eng. JSCE 2005, 52, 741-745. (In Japanese)

19. Mizutani, N.; Usami, A.; Koike, T. Experimental study on behavior of drifting boats due to tsunami and their collision forces. Annu. J. Civ. Eng. ocean, JSCE 2007, 23, 63-68. (In Japanese)

20. Arikawa, T.; Ohtsubo, D.; Nakano, F.; Shimosako, K.; Ishikawa, N. Large Model Tests of Drifting Container Impact Force due to Surge Front Tsunami. Proc. Coast. Eng. JSCE 2007, 54, 846-850. [CrossRef]

21. Arikawa, T.; Washizaki, M. Large Scale Tests on Concrete Wall Destruction by Tsunami with Driftwood. J. Jpn. Soc. Civ. Eng. Ser. B2 Coast. Eng. 2010, 66, 781-785. [CrossRef]

22. Ikeno, M.; Kihara, N.; Takabatake, D. Simple and practical estimation of movement possibility and collision force of de-bris due to tsunami. J. JSCE B2 Coast. Eng. 2013, 69, 861-865. (In Japanese)

23. Ikeno, M.; Takabatake, D.; Kihara, N.; Kaida, H.; Miyagawa, Y.; Shibayama, A. Collision Experiment of Woody Debris and Improvement of Collision Force Formula. J. Jpn. Soc. Civ. Eng. Ser. B2 Coast. Eng. 2015, 71, 1021-1026. [CrossRef]

24. Takabatake, D.; Kihara, N.; Miyagawa, Y.; Kaida, H.; Shibayama, A.; Ikeno, M. Axial Stiffness Model for Estimating Floating Debris Impact Forces due to Tsunami. J. Jpn. Soc. Civ. Eng. Ser. B2 Coast. Eng. 2015, 71, 1015-1020. [CrossRef]

25. Arita, K. A study on the strength of ships and other structures against collision. Rep. Natl. Marit. Res. Inst. 1988, 25, 35-125. (In Japanese) 